\title{
A nine year follow up study of renal effects in workers exposed to cadmium in a zinc ore refinery
}

\author{
N J van Sittert, P H Ribbens, B Huisman, D Lugtenburg
}

\begin{abstract}
Renal changes with time have been studied in 14 workers engaged in the production of cadmium (Cd) in a zinc ore refinery. These workers were examined once a year in the period 1980 to 1985 and 13 of them also in 1989. Four of the workers (group A) had been employed in an old Cd plant before 1973 and had received higher exposures to $\mathrm{Cd}$ than the other workers (group B). Average urinary Cd concentrations over the whole study period in workers of group A ranged from 6.9 to $9.2 \mu \mathrm{g} / \mathrm{g}$ creatinine (median $8.4 \mu \mathrm{g} / \mathrm{g}$ ) and in workers of group B from 0.64 to $7 \cdot 1 \mu \mathrm{g} / \mathrm{g}$ creatinine (median $1.9 \mu \mathrm{g} / \mathrm{g}$ ). Renal effects were assessed by the determination of urinary $N$-acetyl- $\beta$-Dglucosaminidase (NAG), $\boldsymbol{\beta}_{2}$-microglobulin $\left(\boldsymbol{\beta}_{2}\right.$ $M)$, retinol binding protein, albumin, total protein, and serum creatinine concentrations and activity. Urinary $\beta_{2}-M$ concentrations in three of four workers of group $A$ were close to or marginally above the upper normal limit during the study period. The $\beta_{2}$-microglobinuria was not, however, progressive. No values outside normal limits were detected for any of the other renal tests in workers of groups $A$ and $B$, related to exposure to $\mathrm{Cd}$. Doseresponse relations showed that urinary $\mathrm{Cd}$ correlated significantly with urinary NAG activity and total protein and $\beta_{2}-M$. The earliest change induced by $\mathrm{Cd}$ was seen for urinary NAG activity within normal limits of NAG excretion. The regression lines were similar in the surveys between 1981 and 1989, indicative
\end{abstract}

\footnotetext{
Shell Internationale Petroleum Maatschappij BV, Health, Safety, and Environment Division, Biomedical Services, PO Box 162, 2501 AN The Hague, The Netherlands

N J van Sittert, B Huisman,

Budelco BV, Occupational Health Department, PO Box 2001, 6020 AA Budel Dorplein, The Netherlands P H Ribbens

Erasmus University, Department of Epidemiology and Biostatistics, PO Box 1738, 3000 DR Rotterdam, The Netherlands

D Lugtenburg
}

of no progression to higher values for any of the renal tests. The current biological exposure index (BEI) of $10 \mu \mathrm{g} / \mathrm{g}$ creatinine for workers exposed to $\mathrm{Cd}$, set by the American Conference of Governmental Industrial Hygienists (ACGIH), therefore seems justified, although the safety margin is small. The World Health Organisation recommended limit and ACGIH (1992-3) proposed limit of 5 $\mu \mathrm{g} / \mathrm{g}$ creatinine would provide a much larger safety margin, and could be regarded as an action point for increased health surveillance.

(British Fournal of Industrial Medicine 1950;50:603-612)

It is well established that occupational exposure to cadmium (Cd) may produce renal changes, as shown by increased urinary excretion of low molecular weight proteins such as $\beta_{2}$-microglobulin $\left(\beta_{2}\right.$ $M)$ and retinol binding protein (RBP) and of high molecular weight proteins such as albumin..$^{1-6}$ The first tests may be used to detect impairment of proximal tubular function whereas the assay of urinary albumin is used to study the integrity of the glomerulus. Recent investigations have also shown that exposure to $\mathrm{Cd}$ may produce increased amounts of urinary enzymes such as $\mathrm{N}$-acetyl- $\beta$-Dglucosaminidase (NAG), a lysosomal enzyme used for the assessment of proximal tubular injury. ${ }^{5-7}$ The irreversibility of $\mathrm{Cd}$ proteinuria has been shown in several studies on workers with previous high exposure to $\mathrm{Cd}^{2{ }^{23-10}}$ Also a progressive reduction of the glomerular filtration rate was found despite removal from exposure. ${ }^{10}$ In these studies average urinary $\mathrm{Cd}$ concentrations (a reflection of Cd body burden) were above $10 \mu \mathrm{g} / \mathrm{g}$ creatinine, the value which is currently considered as the tentative biological exposure limit below which no proteinuria induced by Cd develops. ${ }^{112}$ The validity of this limit should preferably be verified in longitudinal studies on workers with urinary Cd concentrations below $10 \mu \mathrm{g} / \mathrm{g}$ creatinine. Few studies have been published on the possible long term renal effects of low exposure to $\mathrm{Cd}$. In cross sectional studies no abnormalities were reported in renal parameters of workers with average urinary $\mathrm{Cd}$ 
concentrations below $5 \mu \mathrm{g} / \mathrm{g}$ creatinine. ${ }^{513}$ In two recent studies, however, a clear correlation was found between urinary $\mathrm{Cd}$ concentrations below 10 $\mu \mathrm{g} / \mathrm{g}$ creatinine and urinary NAG excretion. ${ }^{14} 15$ The study reported here is a nine year follow up of a previously reported study on Cd workers in a zinc ore refinery, who at the beginning of the study, had urinary $\mathrm{Cd}$ concentrations ranging from 0.4 to 9.6 $\mu \mathrm{g} / \mathrm{g}$ creatinine. At that time, in two of 15 workers urinary $\beta_{2}-\mathrm{M}$ excretions were close to or marginally above the upper normal limit. ${ }^{13}$ The aim of this follow up study was to investigate whether any renal changes with time occurred in these workers.

\section{Methods}

\section{FACTORY AND EXPOSURES}

Our study was conducted in a zinc ore refinery in the southern part of The Netherlands. Until 1973 high temperature furnaces were used for the recovery of $\mathrm{Zn}$ and $\mathrm{Cd}$. In 1973 the process changed from the original thermal into an electrolytic process. After leaching and purification, the $\mathrm{Cd}$ is deposited from the solution on to aluminum electrodes in electrolysis cells. The $\mathrm{Cd}$ is removed from the electrodes and then melted into balls or sticks in the $\mathrm{Cd}$ unit. In this unit the highest potential exposures to $\mathrm{Cd}$ take place.

No air measurements of $\mathrm{Cd}$ were carried out before 1977, but it can be assumed that exposures to $\mathrm{Cd}$ during the thermal process were much higher than during the electrolytic process. Since 1977 periodic stationary air sampling was carried out at different locations in the leaching section (about seven samples a year), the purification section (about 25 samples a year), and the Cd section (about 70 samples a year) of the zinc refinery (sampling times 10 minutes). The airborne $\mathrm{Cd}$ concentrations were highest in the purification and the $\mathrm{Cd}$ sections and much lower in the leaching section. The average airborne $\mathrm{Cd}$ concentration in the $\mathrm{Cd}$ section decreased from about $19 \mu \mathrm{g} / \mathrm{m}^{3}$ in 1977 to about $8 \mu \mathrm{g} / \mathrm{m}^{3}$ in 1982 and thereafter concentrations fluctuated between $4 \mu \mathrm{g} / \mathrm{m}^{3}$ and $25 \mu \mathrm{g} / \mathrm{m}^{3}$.

Airborne $\mathrm{Cd}$ concentrations (eight hour time weighted average) from personal samplers were measured for 25 workers in 1984, 26 workers in 1986 , and 37 workers in 1990. Concentrations showed a decreasing trend with time ranging from 5 to $91 \mu \mathrm{g} / \mathrm{m}^{3}$ (average $29 \mu \mathrm{g} / \mathrm{m}^{3}$ ) in 1984 , from 4 to $74 \mu \mathrm{g} / \mathrm{m}^{3}$ (average $20 \mu \mathrm{g} / \mathrm{m}^{3}$ ) in 1986, and from 3 to $38 \mu \mathrm{g} / \mathrm{m}^{3}$ (average $11 \mu \mathrm{g} / \mathrm{m}^{3}$ ) in 1990 . These concentrations, however, overestimate the average daily exposures of the workers because they were measured when workers were engaged in selected activities in the $\mathrm{Cd}$ section with the highest potential exposure to $\mathrm{Cd}$.
STUDY POPULATIONS

At the beginning of the survey in 1980,15 male workers of the Cd plant participated in the study. These workers were divided into two groups. Group A comprised four workers who had worked for more than one year in the old plant with the thermal process. One employee in this group was removed from the plant in 1983 and retired in 1986. He remained in the cohort and received follow up health assessments until the end of this study. Group B comprised the remaining 11 workers who had exclusively worked in the new $\mathrm{Cd}$ plant with the electrolytic process. Two employees in this group left the company during the survey period; one had his last health assessment in 1983 and one in 1985. Four other employees in group B were transferred during the survey to another part of the zinc refinery without exposure to $\mathrm{Cd}$, but had health assessments until the end of the study. Two groups of age matched control male subjects were also examined, one during the first survey (group C) and one at the end of the study (group D). Group C comprised 14 men who were employed in the zinc refinery but who had never worked in the Cd section. Group D comprised 14 male employees from the occupational health department of the Shell refinery, Rotterdam. Subjects in groups A, B, and C may have had some occupational exposure to lead, but average concentrations in blood over the period 1980 to 1989 were below $300 \mu \mathrm{g} / 1$. Subjects in group D had never had occupational exposure to heavy metals. Table 1 summarises the characteristics of the four populations.

HEALTH ASSESSMENT AND COLLECTION OF SAMPLES Health assessments were carried out once a year during the period 1980 to 1985 inclusive and in 1989. Two workers in group B did not attend in 1981. In 1984 one worker in group $A$ and one in group B did not attend. Concentrations of $\mathrm{Cd}$ were determined in blood and urine since 1980. Due to technical problems all results for urinary $\mathrm{Cd}$ and some results for $\mathrm{Cd}$ in blood were discarded for 1980. The renal tests carried out were measurement of $\beta_{2}-\mathrm{M}$ (1980-89), total protein (1980-89), NAG (1981-89), albumin (1985 and 89), and retinol binding protein (1989) in urine, and creatinine $(1980,85$, and 89$)$ and $\beta_{2}-M(1980)$ in serum. Urinary excretion of $\mathrm{Cd}$ and proteins were adjusted for urinary creatinine concentrations. Spot urine samples were collected in $\mathrm{Cd}$ free polyethylene containers. Two hours before urine collection each worker was asked to ingest $3 \mathrm{~g}$ of sodium bicarbonate tablets to produce a $\mathrm{pH}$ above 5.7 in the urine sample. At lower $\mathrm{pH} \beta_{2}-\mathrm{M}$ is degraded in the bladder. ${ }^{16}$ Samples collected from persons with urine samples that were too acid were discarded. Urine 
Table 1 Characteristics of $C d$ exposed groups $A$ and $B$ and of control groups $C$ and $D$

\begin{tabular}{|c|c|c|c|c|}
\hline & Group $A$ & Group B & Group $C$ & Group D \\
\hline \multicolumn{5}{|l|}{$\begin{array}{l}\text { No of subjects in study groups } \\
\text { (employed in Cd plant in parentheses): }\end{array}$} \\
\hline Survey October 1980 & $4(4)$ & $11(11)$ & $14(0)$ & - \\
\hline Survey June 1985 & $4(3)$ & $10 *(6)$ & - & - \\
\hline Survey November 1989 & 4 (3) & $9+(5)$ & - & $14(0)$ \\
\hline \multicolumn{5}{|l|}{ Age (mean (SD)): } \\
\hline Survey October 1980 & $43 \cdot 2(7 \cdot 1)$ & $35 \cdot 2(9 \cdot 1)$ & $40 \cdot 5(11 \cdot 0)$ & - \\
\hline Survey June 1985 & $47.8(7 \cdot 4)$ & $38.7(9 \cdot 2)$ & - & \\
\hline Survey November 1989 & $52 \cdot 2(7 \cdot 1)$ & $43.1(9 \cdot 4)$ & - & $43 \cdot 2(11 \cdot 3)$ \\
\hline \multicolumn{5}{|l|}{ No of cigarette smokers: } \\
\hline Survey October 1980 & 4 & 7 & 11 & - \\
\hline Survey June 1985 & 4 & 6 & - & - \\
\hline Survey November 1989 & 4 & 7 & - & 2 \\
\hline \multicolumn{5}{|l|}{ Lead in blood $(\mu \mathrm{g} / \mathrm{l})$ (mean (range)): } \\
\hline Survey October 1980 & $223(178-253)$ & $174(101-276)$ & $259(144-471)$ & - \\
\hline Survey June 1985 & $211(154-260)$ & $174(105-274)$ & - & \\
\hline \multirow{2}{*}{\multicolumn{5}{|c|}{ Years of employment in the old Cd plant }} \\
\hline & & & & \\
\hline \multirow{2}{*}{\multicolumn{5}{|c|}{ Total years of employment in the Cd plant }} \\
\hline & & & & \\
\hline Survey October 1980 & $15 \cdot 0(10-25 \cdot 8)$ & $5 \cdot 1(0 \cdot 8-7 \cdot 1)$ & 0 & - \\
\hline Survey June 1985 & $19 \cdot 1(15-28)$ & $9 \cdot 0(3 \cdot 0-13 \cdot 5)$ & - & - \\
\hline Survey November 1989 & $22 \cdot 3(19-28)$ & $12 \cdot 0(3 \cdot 0-15 \cdot 8)$ & - & 0 \\
\hline \multicolumn{5}{|l|}{$\begin{array}{l}\text { Years since removal from Cd exposure } \\
\text { (mean, range, and No of persons) }\end{array}$} \\
\hline Survey October 1980 & 0 & 0 & - & - \\
\hline Survey June 1985 & $2 \cdot 5(n=1)$ & $\begin{array}{c}2 \cdot 4(1 \cdot 5-3 \cdot 0) \\
(n=4)\end{array}$ & - & - \\
\hline Survey November 1989 & $6 \cdot 8(n=1)$ & $\begin{array}{c}5 \cdot 9(4 \cdot 2-6 \cdot 8) \\
(n=4)\end{array}$ & - & - \\
\hline
\end{tabular}

^One subject left company in 1984; fOne subject left company in 1987.

samples were stored at $-20^{\circ} \mathrm{C}$ until analysis. Blood was collected by venepuncture in $\mathrm{Cd}$ free tubes and stored at $-20^{\circ} \mathrm{C}$.

\section{ANALYTICAL METHODS}

Concentrations of $\mathrm{Cd}$ in blood and urine were determined in duplicate with electrothermal atomisation atomic absorption spectrometry (PerkinElmer model 4000). Blood samples $(300 \mu \mathrm{l})$ were deproteinated with $1750 \mu \mathrm{l} 1.5 \mathrm{M}$ nitric acid and urine samples $(0.5 \mathrm{ml})$ were acidified with $10 \mu \mathrm{l}$ $65 \%$ nitric acid and diluted with $1 \mathrm{ml}$ of water. ${ }^{17}$ Commercial blood samples (Kontrollblut, Behringwerke AG and Seronorm, Nyegaard) were used as calibration standards for $\mathrm{Cd}$ concentrations in blood. The accuracy of the test was assessed by participation (since 1982) in an external quality assessment scheme. ${ }^{18}$ Concentrations of $\mathrm{Cd}$ in blood were within $10 \%$ of the mean value of all participating laboratories. The average precision of the test during 1982 to 1989 , expressed as the coefficient of variation (CV) of duplicate routine analyses, was $5 \%$ (number of duplicate analyses varied between 10 and 27). Concentrations of $\mathrm{Cd}$ in urine were determined with the standard addition technique. The accuracy was checked from commercial control urine samples with known $\mathrm{Cd}$ concentrations (Lanonorm-Metalle, Behringwerke AG). The average precision of the test was $7 \%$. Urinary and serum $\beta_{2}-\mathrm{M}$ were measured by a radioimmunoassay (Phadebas, Pharmacia Diagnostics).

The coefficient of variation of duplicate analyses for both tests averaged $7 \%$. The activity of urinary NAG was determined with a spectrophotometric assay. ${ }^{19}$ The average precision of the test was $5 \%$. Urinary protein was measured by precipitation of proteins with a mixture of phosphotungstic acid, hydrochloric acid, and ethanol and determination of the amount of protein with the biuret method. ${ }^{20}$ The average precision of the test was $8 \%$. Urinary albumin was determined in the survey of 1985 with an electroimmunoassay. The precision of this method was $2-5 \% .^{21}$ A latex immunoassay was used for the determinations of urinary albumin and of urinary retinol binding protein in the survey of 1989. ${ }^{22}{ }^{23}$ The precision of these assays was between $4 \%$ and $10 \%$. Serum and urinary creatinine concentrations were determined on a Hitachi 705 autoanalyser by the standard Jaffe method. The average precision of these assays was $3 \%$.

\section{REFERENCE GROUPS}

Several control groups were used to establish reference values for the parameters measured. These comprised male employees of the Shell refinery in Rotterdam not exposed to known nephrotoxic agents. For each parameter the same methods were used as for the groups exposed to Cd. Table 2 shows the reference values. Values of a parameter 
Table 2 Reference groups and reference values of parameters investigated during the survey period 1980-89

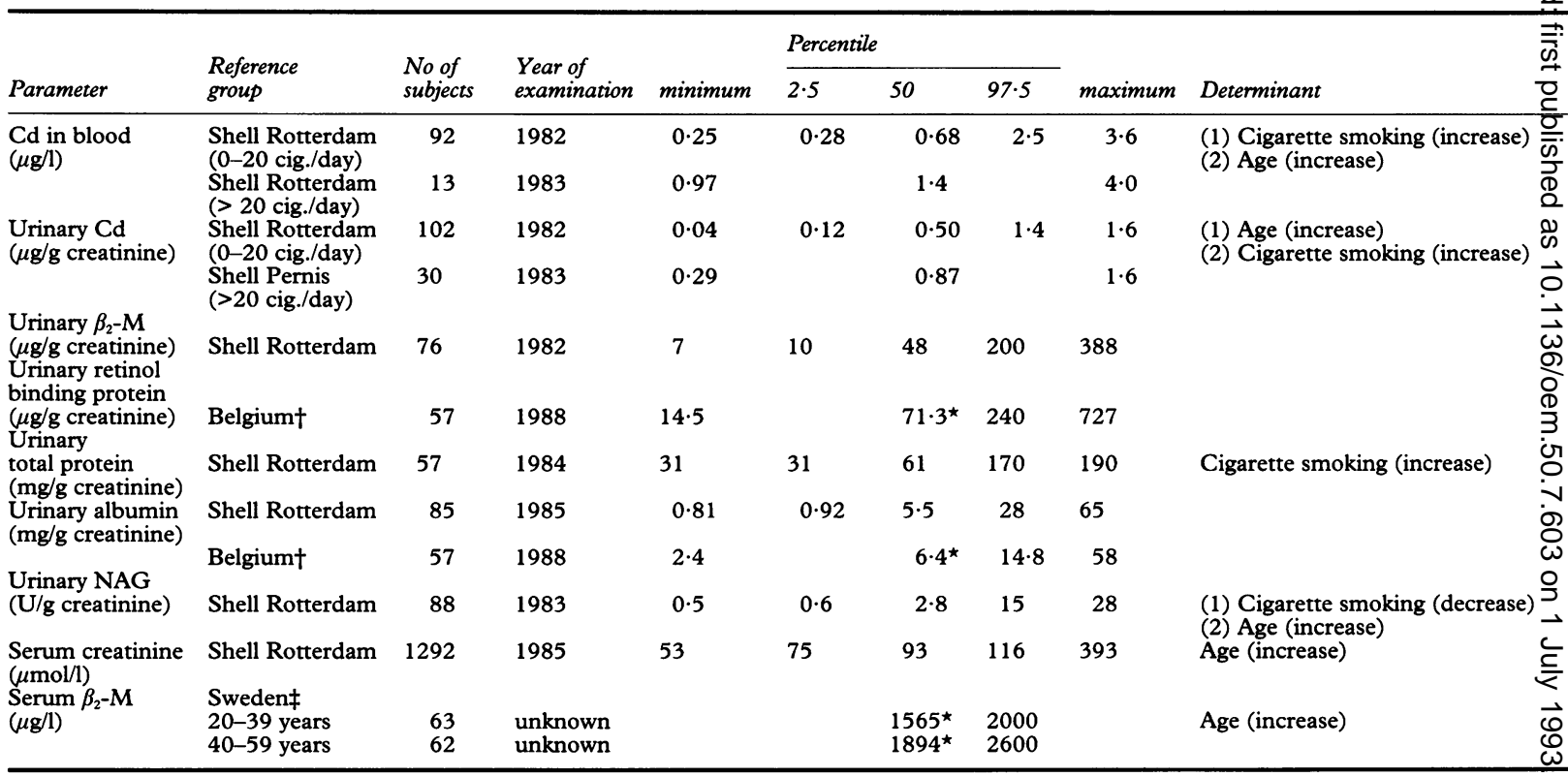

${ }^{\star}$ Mean values; ffrom Bernard $e t a l^{6}$ and Bernard. ${ }^{23}$; $¥$ Pharmacia Diagnostics AB, Uppsala, Sweden.

Table $3 C d$ concentration in blood and urine and renal function parameters: summary of a nine year follow up ( $A$ and $B$ Cd exposed groups; $C$ and $D$ control groups)

\begin{tabular}{|c|c|c|c|c|c|c|c|c|c|}
\hline \multirow[b]{2}{*}{ Variable } & \multirow[b]{2}{*}{ Group } & \multicolumn{2}{|c|}{ October 1980} & \multicolumn{2}{|c|}{ October 1981} & \multicolumn{2}{|c|}{ May 1982} & \multicolumn{2}{|c|}{ February 1983} \\
\hline & & No & Median (range) & $\overline{N o}$ & Median (range) & No & Median (range) & & Median (range) \\
\hline $\begin{array}{l}\text { Cd in blood } \\
(\mu \mathrm{g} / \mathrm{l})\end{array}$ & $\begin{array}{l}\text { A } \\
\text { B } \\
\text { C } \\
\text { D }\end{array}$ & $\begin{array}{l}3 \\
9 \\
8\end{array}$ & $\begin{array}{l}7 \cdot 4(7 \cdot 1-10 \cdot 0)^{\star} \\
4 \cdot 7(0 \cdot 9-11 \cdot 6) \\
2 \cdot 4(0 \cdot 2-7 \cdot 3)\end{array}$ & $\begin{array}{l}4 \\
9\end{array}$ & $\begin{array}{l}7 \cdot 5(6 \cdot 8-9 \cdot 1) \\
4 \cdot 8(0 \cdot 7-10 \cdot 7)\end{array}$ & & $\begin{array}{l}9 \cdot 0(7 \cdot 1-9 \cdot 2) \\
2 \cdot 9(1 \cdot 0-8 \cdot 8)\end{array}$ & & $\begin{array}{l}7 \cdot 6(7 \cdot 1-8 \cdot 0) \\
2 \cdot 6(0 \cdot 9-8 \cdot 1)\end{array}$ \\
\hline $\begin{array}{l}\text { Urinary Cd } \\
(\mu \mathrm{g} / \mathrm{g} \text { creatinine }\end{array}$ & $\begin{array}{l}\text { A } \\
\text { B } \\
\text { C } \\
\text { D }\end{array}$ & & & $\begin{array}{l}4 \\
9\end{array}$ & $\begin{array}{l}7 \cdot 4(5 \cdot 8-9 \cdot 6) \\
2 \cdot 8(0 \cdot 4-7 \cdot 5)\end{array}$ & $\begin{array}{l}4 \\
11\end{array}$ & $\begin{array}{l}9 \cdot 3(8 \cdot 0-10 \cdot 3) \\
1.9(0 \cdot 4-8 \cdot 8)\end{array}$ & $\begin{array}{l}4 \\
11\end{array}$ & $\begin{array}{l}7 \cdot 2(6 \cdot 0-10 \cdot 0) \\
1 \cdot 8(0 \cdot 5-5 \cdot 9)\end{array}$ \\
\hline $\begin{array}{l}\text { Urinary } \beta_{2}-M \\
(\mu \mathrm{g} / \mathrm{g} \text { creatinine })\end{array}$ & $\begin{array}{l}\text { A } \\
\text { B } \\
\text { C } \\
\text { D }\end{array}$ & $\begin{array}{l}4 \\
11 \\
12\end{array}$ & $\begin{array}{l}150(100-400)^{\star \star} \\
58(34-75) \\
53(15-125)\end{array}$ & $\begin{array}{l}4 \\
9\end{array}$ & $\begin{array}{l}201(70-312) \\
53(42-119)\end{array}$ & $\begin{array}{l}4 \\
10\end{array}$ & $\begin{array}{l}217(77-410) \\
70(49-162)\end{array}$ & $\begin{array}{l}4 \\
11\end{array}$ & $\begin{array}{l}316(91-473) \\
75(56-120)\end{array}$ \\
\hline $\begin{array}{l}\text { Urinary retinol } \\
\text { binding protein } \\
(\mu \mathrm{g} / \mathrm{g} \text { creatinine }\end{array}$ & $\begin{array}{l}\text { A } \\
\text { B } \\
\text { C } \\
\text { D }\end{array}$ & & & & & & & & \\
\hline $\begin{array}{l}\text { Urinary total protein } \\
(\mu \mathrm{g} / \mathrm{g} \text { creatinine }\end{array}$ & $\begin{array}{l}\text { A } \\
\text { B } \\
\text { C } \\
\text { D }\end{array}$ & $\begin{array}{l}4 \\
11 \\
13\end{array}$ & $\begin{array}{l}51(38-81) \\
52(31-247) \\
48(19-65)\end{array}$ & $\begin{array}{l}4 \\
9\end{array}$ & $\begin{array}{l}75(40-111) \\
39(15-337)\end{array}$ & $\begin{array}{l}4 \\
11\end{array}$ & $\begin{array}{l}76(61-96) \\
45(34-210)\end{array}$ & $\begin{array}{l}4 \\
11\end{array}$ & $\begin{array}{l}78(37-85) \\
54(24-419)\end{array}$ \\
\hline $\begin{array}{l}\text { Urinary albumin } \\
\text { (mg/g creatinine }\end{array}$ & $\begin{array}{l}\text { A } \\
\text { B } \\
\text { C } \\
\text { D }\end{array}$ & & & & & & & & \\
\hline $\begin{array}{l}\text { Urinary NAG } \\
\text { (U/g creatinine) }\end{array}$ & $\begin{array}{l}\text { A } \\
\text { B } \\
\text { C } \\
\text { D }\end{array}$ & & & $\begin{array}{l}4 \\
9\end{array}$ & $\begin{array}{l}4 \cdot 4(2 \cdot 0-7 \cdot 7) \\
2 \cdot 6(1 \cdot 6-5 \cdot 4)\end{array}$ & $\begin{array}{l}4 \\
10\end{array}$ & $\begin{array}{l}5 \cdot 1(3 \cdot 7-11 \cdot 2) \\
2 \cdot 9(1 \cdot 4-6 \cdot 0)\end{array}$ & $\begin{array}{l}4 \\
11\end{array}$ & $\begin{array}{l}4 \cdot 5(2 \cdot 8-8 \cdot 6) \\
3 \cdot 6(0 \cdot 5-7 \cdot 7)\end{array}$ \\
\hline $\begin{array}{l}\text { Serum creatinine } \\
(\mu \mathrm{ml} / \mathrm{l})\end{array}$ & $\begin{array}{l}\text { A } \\
\text { B } \\
\text { C } \\
\text { D }\end{array}$ & $\begin{array}{l}3 \\
11 \\
14\end{array}$ & $\begin{array}{l}103(95-109) \\
91(88-109) \\
97(52-120)\end{array}$ & & & & & & \\
\hline$\underset{(\mu \mathrm{g} / \mathrm{l})}{\operatorname{Serum}} \beta_{2}-\mathrm{M}$ & $\begin{array}{l}\text { A } \\
\text { B } \\
\text { C } \\
\text { D }\end{array}$ & $\begin{array}{l}4 \\
11 \\
14\end{array}$ & $\begin{array}{l}1785(1580-2540) \\
1760(1440-1900) \\
1690(1060-1980)\end{array}$ & & & & & & \\
\hline
\end{tabular}


above the 97.5 percentile were considered abnormal. The table also shows the influence of age and of cigarette smoking on the tests.

\section{STATISTICS}

The Wilcoxon or Mann-Whitney test was used to compare the results for the groups exposed to $\mathrm{Cd}$ and the controls. A paired $t$ test was used to compare the results of the first and the last survey. The prevalences of abnormal test results from groups A, B, C, and D and in the controls were analysed by a standard one tailed binomial test with a null probability of 0.025 .

Time trends in individual persons over the period 1980 to 1989 were analysed with the Spearman rank test ${ }^{24}$ if four or more observations were available. On a group basis individual results were pooled, with a binomial test with a null-probability of 0.05 . Time trends of urinary albumin and serum creatinine on a group basis were investigated with a binomial test (null-probability $0 \cdot 50$ ). Associations between urinary $\mathrm{Cd}$ concentrations and renal parameters were tested by Spearman rank correlation analyses. In all tests, $p$ values below 0.05 were considered to be statistically significant.

\begin{tabular}{|c|c|c|c|c|}
\hline \multicolumn{2}{|c|}{ November 1984} & \multicolumn{2}{|c|}{ fune 1985} & \multirow{2}{*}{$\frac{\text { November } 1989}{\text { No Median (range) }}$} \\
\hline No & Median (range) & No & Median (range) & \\
\hline $\begin{array}{l}3 \\
9\end{array}$ & $\begin{array}{l}6 \cdot 8(6 \cdot 5-7 \cdot 5) \\
2 \cdot 8(1 \cdot 4-5 \cdot 1)\end{array}$ & $\begin{array}{l}4 \\
10\end{array}$ & $\begin{array}{l}5 \cdot 5(5 \cdot 3-6 \cdot 0) \\
2 \cdot 1(0 \cdot 9-4 \cdot 0)\end{array}$ & $\begin{array}{ll}4 & 5 \cdot 5(4 \cdot 2-5 \cdot 7)^{\star \star} \\
9 & 2 \cdot 0(0 \cdot 7-4 \cdot 3)^{\star \star}\end{array}$ \\
\hline 3 & $9 \cdot 1(7 \cdot 9-10 \cdot 8)$ & 4 & $\begin{array}{l}9 \cdot 3(7 \cdot 6-10 \cdot 1) \\
9\end{array}$ & $\begin{array}{l}140 \cdot 8(0 \cdot 5-1 \cdot 4) \\
48 \cdot 0(4 \cdot 5-8 \cdot 9)^{\star \star} \\
1 \cdot 8(0 \cdot 6-7 \cdot 5)^{\star \star}\end{array}$ \\
\hline \multirow[t]{2}{*}{$\begin{array}{l}3 \\
7\end{array}$} & $\begin{array}{l}137(95-397) \\
64(35-88)\end{array}$ & $\begin{array}{l}9 \\
4\end{array}$ & $\begin{array}{l}2 \cdot 4(0 \cdot 5-6 \cdot 2) \\
386(73-413)\end{array}$ & $\begin{array}{ll}14 & 0 \cdot 5(0 \cdot 1-0 \cdot 8) \\
4 & 184(150-506)^{\star \star} \\
8 & 73(34-104)\end{array}$ \\
\hline & & 9 & $83(53-152)$ & $\begin{array}{ll}12 & 83(56-139) \\
4 & 77(14-122) \\
9 & 54(31-86)\end{array}$ \\
\hline \multirow[t]{2}{*}{$\begin{array}{l}3 \\
7\end{array}$} & $\begin{array}{l}44(34-80) \\
48(31-71)\end{array}$ & $\begin{array}{l}4 \\
9\end{array}$ & $\begin{array}{l}65(20-93) \\
42(28-384)\end{array}$ & $\begin{array}{ll}14 & 56(28-131) \\
4 & 43(28-67) \\
9 & 46(23-334)\end{array}$ \\
\hline & & $\begin{array}{l}4 \\
9\end{array}$ & $\begin{array}{l}6 \cdot 8(4 \cdot 2-11) \\
8 \cdot 3(4 \cdot 1-261)\end{array}$ & $\begin{array}{ll}14 & 31(10-65) \\
4 & 4 \cdot 9(2 \cdot 4-7 \cdot 3) \\
9 & 6 \cdot 4(3 \cdot 4-297)\end{array}$ \\
\hline \multirow[t]{3}{*}{$\begin{array}{l}3 \\
7\end{array}$} & $\begin{array}{l}6 \cdot 2(4 \cdot 4-8 \cdot 4) \\
2 \cdot 3(1 \cdot 3-3 \cdot 2)\end{array}$ & $\begin{array}{l}4 \\
9\end{array}$ & $\begin{array}{l}6 \cdot 2(2 \cdot 7-9 \cdot 6) \\
2 \cdot 4(0 \cdot 6-6 \cdot 3)\end{array}$ & $\begin{array}{ll}14 & 4 \cdot 9(2 \cdot 8-9 \cdot 2) \\
4 & 6 \cdot 7(3 \cdot 9-8 \cdot 2)^{\star} \\
9 & 3 \cdot 8(1 \cdot 5-6 \cdot 3)\end{array}$ \\
\hline & & $\begin{array}{l}4 \\
7\end{array}$ & $\begin{array}{l}99(88-109) \\
92(81-106)\end{array}$ & $\begin{array}{ll}14 & 2 \cdot 9(1 \cdot 8-6 \cdot 2) \\
4 & 97(88-108) \\
9 & 89(81-103)\end{array}$ \\
\hline & & & & $1493(76-104)$ \\
\hline
\end{tabular}

\section{Results}

CD WORKERS AND CONTROLS

Table 3 summarises the results of the exposure and renal parameters measured in the period 1980 to 1989. In the survey of $1980, \mathrm{Cd}$ workers in group A had significantly higher concentrations of $\mathrm{Cd}$ in blood and $\beta_{2}-\mathrm{M}$ in urine compared with the control group C. No significant differences were found for urinary total protein, serum creatinine, and serum $\beta_{2}-\mathrm{M}$ concentration. Urinary retinol binding protein, NAG, and albumin were not analysed in 1980 and the results of urinary $\mathrm{Cd}$ were unreliable due to technical problems and were discarded from the analyses. Workers in the low exposure group B had a higher median $\mathrm{Cd}$ concentration in blood than the controls, but this difference was not significant. Neither were significant differences found for any of the other parameters. Workers in group A had significantly higher concentrations of urinary $\beta_{2}-\mathrm{M}$ compared with group $B$, but no significant differences were found for any other parameters.

In the survey of 1989, workers in group A had significantly higher concentrations of $\mathrm{Cd}$ in blood and urine and of urinary $\beta_{2}-\mathrm{M}$ and NAG compared with the control group $D$. The values for urinary retinol binding protein, total protein, albumin, and serum creatinine did not differ between these groups. Workers in group B also had significantly higher Cd concentrations in blood and urine compared with the control group, but no other significant differences were found. In comparison with workers in group B, workers in group A had significantly higher concentrations of $\mathrm{Cd}$ in blood and urine and of urinary $\beta_{2}-\mathrm{M}$. Other values did not differ between the groups.

Table 4 shows the prevalences of abnormal test results in the groups exposed to $\mathrm{Cd}$ and in the controls at the first and the last survey. These prevalences were established by taking as cut off values the 97.5 percentile of each test from the reference groups in table 2 . For urinary albumin $15 \mathrm{mg} / \mathrm{g}$ creatinine was taken as the cut off level, however, because higher values are considered to indicate microalbuminuria. ${ }^{61025}$

During the first survey (1980), prevalences of abnormal $\mathrm{Cd}$ concentrations in blood were significantly raised in workers of groups $\mathbf{A}$ and $\mathbf{B}$ and, surprisingly, in the local control group C. The last might have been due to a combination of environmental exposure to $\mathrm{Cd}$ and a high smoking rate of the workers. Prevalences of abnormal urinary Cd values (in 1981) were also significantly increased in workers of groups $\mathrm{A}$ and $\mathrm{B}$. For urinary $\beta_{2}-\mathbf{M}$ the cut off value of $200 \mu \mathrm{g} / \mathrm{g}$ creatinine was only exceeded by one worker of group A. All other tests of renal function were within normal limits for workers in both groups A and B, except for total protein in one worker of group B. This worker had 
Table 4 Prevalence of concentrations outside 97.5 percentile of the reference groups of parameters in the Cd exposed and control groups

\begin{tabular}{|c|c|c|c|c|c|c|}
\hline \multirow[b]{2}{*}{ Variable } & \multicolumn{2}{|l|}{ Group $A$} & \multicolumn{2}{|l|}{ Group B } & \multirow{2}{*}{$\begin{array}{l}\text { Group C } \\
\text { Survey } 1980 \\
\text { No }(\%)\end{array}$} & \multirow{2}{*}{$\begin{array}{l}\text { Group D } \\
\text { Survey } 1989 \\
\text { No (\%) }\end{array}$} \\
\hline & $\begin{array}{l}\text { Survey } 1980 \\
\text { No (\%) }\end{array}$ & $\begin{array}{l}\text { Survey } 1989 \\
\text { No (\%) }\end{array}$ & $\begin{array}{l}\text { Survey } 1980 \\
\text { No (\%) }\end{array}$ & $\begin{array}{l}\text { Survey } 1989 \\
\text { No (\%) }\end{array}$ & & \\
\hline $\begin{array}{l}\text { Cd in blood } \\
\text { Urinary Cd } \\
\text { Urinary } \beta_{2} M \\
\text { Urinary retinol binding protein } \\
\text { Urinary total protein } \\
\text { Urinary NAG } \\
\text { Urinary albumin } \$ \\
\text { Serum creatinine } \\
\text { Serum } \beta_{2} M\end{array}$ & $\begin{array}{l}3 / 3(100)^{\star \star} \\
4 / 4(100)^{\star \star} \dagger \\
1 / 4(25) \\
\text { nd } \\
0 / 4(0) \\
0 / 4(0) \\
0 / 4(0) \ddagger \\
0 / 4(0) \\
0 / 4(0)\end{array}$ & $\begin{array}{l}4 / 4(100)^{\star \star} \\
4 / 4(100)^{\star \star} \\
1 / 4(25) \\
0 / 4(0) \\
0 / 4(0) \\
0 / 4(0) \\
0 / 4(0) \\
0 / 4(0) \\
\text { nd }\end{array}$ & $\begin{array}{l}6 / 9(67)^{\star \star} \\
6 / 9(67)^{\star \star} \dagger \\
0 / 11(0) \\
\text { nd } \\
1 / 11(9) \\
0 / 9(0) \\
2 / 9(22) \ddagger \\
0 / 11(0) \\
0 / 11(0)\end{array}$ & $\begin{array}{l}3 / 9(33)^{\star \star} \\
6 / 9(67)^{\star \star} \\
0 / 8(0) \\
0 / 9(0) \\
1 / 9(11) \\
0 / 9(0) \\
1 / 9(11) \\
0 / 9(0) \\
\text { nd }\end{array}$ & $\begin{array}{l}4 / 8(50)^{\star \star} \\
\text { nd } \\
\text { o/12(0) } \\
\text { nd } \\
\text { o/13(0) } \\
\text { nd } \\
\text { nd } \\
0 / 14(0) \\
0 / 14(0)\end{array}$ & $\begin{array}{l}0 / 14(0) \\
0 / 14(0) \\
0 / 14(0) \\
0 / 14(0) \\
0 / 14(0) \\
0 / 14(0) \\
0 / 14(0) \\
0 / 14(0) \\
\text { nd }\end{array}$ \\
\hline
\end{tabular}

${ }^{\star} \mathrm{p}<0.05 ;{ }^{\star \star} \mathrm{p}<0.01$.

†Survey 1981; $¥$ Survey 1985 ; $\oint$ cut off level $15 \mathrm{mg} / \mathrm{g}$ creatinine; $\mathrm{ND}=$ not determined.

clinical proteinuria (>200 $\mathrm{mg} / \mathrm{g}$ creatinine), unlikely to be associated with exposure to $\mathrm{Cd}$ because he had only worked in the Cd section for 10 months when the health assessment took place. This clinical proteinuria remained unchanged during the period 1980-9 and was confirmed by increased urinary albumin values in the surveys of 1985 and 1989.

During the last survey (1989), significantly increased prevalences of abnormal Cd concentrations in blood and urine were found in workers of groups A and B. In workers of group B, the prevalence of raised Cd in blood was lower than in 1980, reflecting a decrease in Cd concentrations in blood over the period 1980-9. Results of the renal function tests were all within normal values, except for urinary $\beta_{2}-\mathrm{M}$ in the same worker of group $\mathrm{A}$ who had an abnormal concentration in 1980, and for uinary total protein and albumin in the worker of group B who had clinical proteinuria. None of the subjects in the control group D had any values outside normal limits.

COMPARISONS OF 1989 AND 1980-81

Concentrations of $\mathrm{Cd}$ in the blood of workers of groups A and B were significantly lower at the last survey compared with the first. No significant differences were seen in urinary $\mathrm{Cd}$ concentrations of workers of groups $A$ and $B$ between the two surveys. Urinary $\beta_{2}-\mathbf{M}$ concentrations for workers of group A were not significantly different at the 1989 survey compared with 1980 , but were significantly increased in 1989 for workers in group B. By contrast, in group B serum creatinine concentrations were significantly lower in 1989 compared with 1980. No significant differences were seen in serum creatinine of workers in group A between the two surveys. Neither were significant changes found in total protein concentrations between the surveys in 1989 and 1980 and in urinary NAG activity between the surveys in 1989 and 1981 for workers in both groups $\mathbf{A}$ and $\mathbf{B}$.

TRENDS OVER TIME 1980-9

Table 5 shows the number of persons with a significant increase or decrease in exposure and renal function over the period 1980-9. The parameter that showed a significant change in the largest number of workers of both groups $A$ and $B$ was $C d$ concentration in blood. Concentrations were significantly decreased in six out of 14 workers. This decrease occurred particularly between 1980 and 1985 , both in workers who were transferred to

Table 5 Number of workers who showed a significant increase or decrease in Cd in blood and in urinary $C d, \beta_{2} M$, total protein, and NAG over the period 1980-9.

\begin{tabular}{|c|c|c|c|c|c|c|}
\hline & $\begin{array}{l}\text { No of } \\
\text { workers }\end{array}$ & $\begin{array}{l}\text { No of } \\
\text { measurements } \\
\text { per worker }\end{array}$ & Increase & Decrease & No change & $\begin{array}{l}\text { Change on a } \\
\text { group basis } \\
(\alpha=0.05)\end{array}$ \\
\hline $\begin{array}{l}\text { Group A: } \\
\text { Cd in blood } \\
\text { Urinary Cd } \\
\text { Urinary } \beta_{2} M \\
\text { Urinary NAG } \\
\text { Urinary total protein } \\
\text { Group B:^ }\end{array}$ & $\begin{array}{l}4 \\
4 \\
4 \\
4 \\
4\end{array}$ & $\begin{array}{l}5-7 \\
5-6 \\
6-7 \\
5-6 \\
6-7\end{array}$ & $\begin{array}{l}0 \\
0 \\
0 \\
1 \\
0\end{array}$ & $\begin{array}{l}2 \\
0 \\
0 \\
0 \\
0\end{array}$ & $\begin{array}{l}2 \\
4 \\
4 \\
3 \\
4\end{array}$ & $\begin{array}{l}\text { Decrease }(p=0.014) \\
\text { None } \\
\text { None } \\
\text { None } \\
\text { None }\end{array}$ \\
\hline $\begin{array}{l}\text { Cd in blood } \\
\text { Urinary Cd } \\
\text { Urinary } \beta_{2} M \\
\text { Urinary NAG } \\
\text { Urinary total protein }\end{array}$ & $\begin{array}{l}10 \\
10 \\
10 \\
10 \\
10\end{array}$ & $\begin{array}{l}6-7 \\
4-6 \\
5-7 \\
5-6 \\
6-7\end{array}$ & $\begin{array}{l}0 \\
1 \\
3 \\
0 \\
0\end{array}$ & $\begin{array}{l}4 \\
0 \\
0 \\
0 \\
1\end{array}$ & $\begin{array}{r}6 \\
9 \\
7 \\
10 \\
9\end{array}$ & $\begin{array}{l}\text { Decrease }(p<0.01) \\
\text { None } \\
\text { Increase }(p<0.01) \\
\text { None } \\
\text { None }\end{array}$ \\
\hline
\end{tabular}

* One subject left the company in 1984 and too few data were available for statistical analysis. 


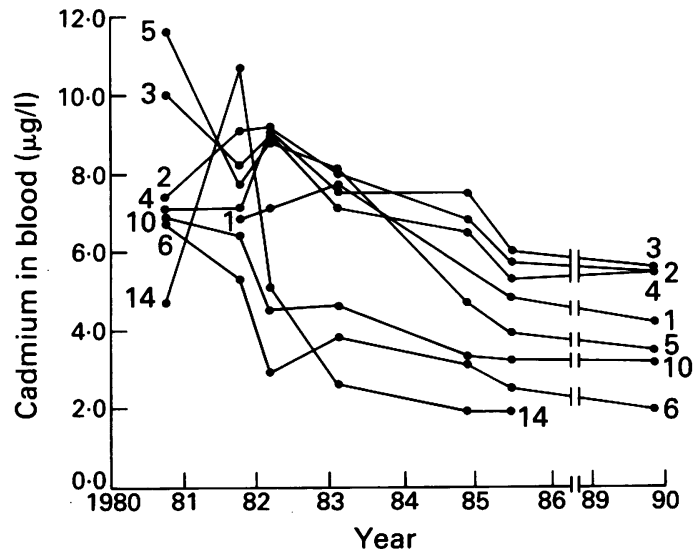

Figure 1 Blood cadmium concentrations in eight workers between 1980 and 1990 (group A: Nos 1, 2, 3 and 4; group $B$ : Nos 5, 6, 10, 14.) Concentrations in Nos 2, 3, 5, 6, and 10 decreased significantly with time.

another plant without exposure to $\mathrm{Cd}$ (fig 1 ; numbers $3,5,10,14)$ and in workers who remained employed in the $\mathrm{Cd}$ section (fig 1 numbers 2 and 6). Figure 2 shows urinary $\beta_{2}-M$ concentrations for four workers in group A over the period 1980-9. The within person variation was large and the coefficients of variation ranged from 18 to $63 \%$. No significant time trend was detected for urinary $\beta_{2}-\mathrm{M}$ in any worker of group A. Surprisingly, urinary $\beta_{2}-\mathrm{M}$ was significantly increased with time in three workers of group B. This time trend was unlikely to be due to exposure to $\mathrm{Cd}$ because in two of the three workers who showed a significant increase, urinary Cd concentrations were within the normal limits of the reference group (table 2). None of the other renal tests showed a trend in concentrations over

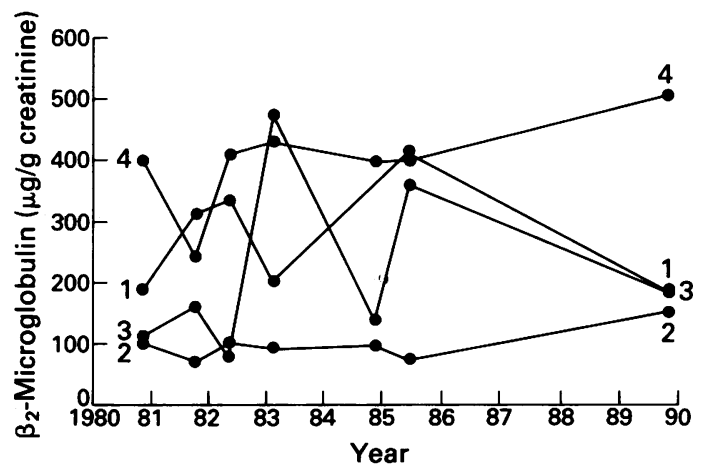

Figure 2 Urinary $\beta_{2}$-microglobulin concentrations in four workers of group $A$ between 1980 and 1990.

the period 1980-9 in workers of groups A and B.

On a group basis no trends were found for serum creatinine concentrations in workers of groups A and $B$ over the period 1980-9 or for urinary albumin over the period 1985-9.

\section{DOSE-RESPONSE RELATIONS}

Dose-response relations were investigated between urinary Cd concentrations, (as a measure of internal dose of $\mathrm{Cd}$ ) and renal function. Dose-response relations were investigated with the average values of each parameter measured in each worker during the period 1980-9, provided that the parameters did not show a time trend (table 6 ). In the exposed groups $\mathrm{Cd}$ concentrations in blood showed such a trend and were not included in the analyses. Also, dose-response relations were investigated in the combined data of exposed workers and controls in the survey of 1989.

Table 6 Renal function variable as a function of urinary $C d$ in the workers exposed to $C d$

\begin{tabular}{|c|c|c|c|c|c|c|c|}
\hline Worker & $\begin{array}{l}\text { Urine } \\
C d \\
(n=4-6) \dagger \\
\mu g / g \text { creatinine }\end{array}$ & $\begin{array}{l}\beta_{2}-M \\
(n=5-7)^{*} \\
\mu g / g \text { creatinine }\end{array}$ & $\begin{array}{l}R B P \\
(n=1) \\
\mu g / g \text { creatinine }\end{array}$ & $\begin{array}{l}\text { Total protein } \\
(n=5-7)^{*} \\
\mu g / g \text { creatinine }\end{array}$ & $\begin{array}{l}\text { Albumin } \\
(n=2) S \\
\mu g / g \text { creatinine }\end{array}$ & $\begin{array}{l}N A G \\
(n=5-6) t \\
\mu g / g \text { creatinine }\end{array}$ & $\begin{array}{l}\text { Serum } \\
\text { creatinine } \\
(n=3) \neq \\
(\mu \mathrm{mol} / \mathrm{l})\end{array}$ \\
\hline $\begin{array}{r}8 \\
13 \\
9 \\
12 \\
6\end{array}$ & $\begin{array}{l}0.64 \\
0.75 \\
1.04 \\
1.48 \\
1.63\end{array}$ & $\begin{array}{l}83 \\
46 \\
69 \\
87 \\
75\end{array}$ & $\begin{array}{l}86 \\
48 \\
81 \\
50 \\
31\end{array}$ & $\begin{array}{l}48 \\
36 \\
43 \\
60 \\
45\end{array}$ & $\begin{array}{l}7 \cdot 3 \\
3 \cdot 4 \\
8 \cdot 7 \\
8 \cdot 0 \\
8 \cdot 9\end{array}$ & $\begin{array}{l}2 \cdot 6 \\
2 \cdot 4 \\
2 \cdot 3 \\
4 \cdot 4 \\
1 \cdot 7\end{array}$ & $\begin{array}{r}90 \\
103 \\
85 \\
86 \\
90\end{array}$ \\
\hline Median & 1.04 & 75 & 50 & 45 & $8 \cdot 0$ & $2 \cdot 4$ & 90 \\
\hline $\begin{array}{r}11 \\
14 \\
7 \\
10\end{array}$ & $\begin{array}{l}2 \cdot 10 \\
3 \cdot 02 \\
3.63 \\
3 \cdot 89\end{array}$ & $\begin{array}{r}47 \\
67 \\
67 \\
101\end{array}$ & $\begin{array}{l}54 \\
-77 \\
50\end{array}$ & $\begin{array}{r}41 \\
60 \\
39 \\
322\end{array}$ & $\begin{array}{c}13 \cdot 2 \\
7 \cdot 7 \\
5 \cdot 8 \\
279\end{array}$ & $\begin{array}{l}2 \cdot 6 \\
4 \cdot 4 \\
5 \cdot 5 \\
4 \cdot 1\end{array}$ & $\begin{array}{r}91 \\
87 \\
99 \\
105\end{array}$ \\
\hline Median & 3.33 & 67 & 54 & 40 & $10 \cdot 5$ & $4 \cdot 2$ & 95 \\
\hline $\begin{array}{l}1 \\
5 \\
3 \\
2 \\
4\end{array}$ & $\begin{array}{l}6.95 \\
7 \cdot 11 \\
8 \cdot 41 \\
8 \cdot 42 \\
9 \cdot 18\end{array}$ & $\begin{array}{r}272 \\
65 \\
215 \\
97 \\
398\end{array}$ & $\begin{array}{r}113 \\
66 \\
41 \\
14 \\
122\end{array}$ & $\begin{array}{l}72 \\
49 \\
59 \\
49 \\
72\end{array}$ & $\begin{array}{l}6 \cdot 3 \\
7 \cdot 2 \\
3 \cdot 3 \\
6 \cdot 1 \\
8 \cdot 5\end{array}$ & $\begin{array}{l}4 \cdot 0 \\
1 \cdot 9 \\
5 \cdot 0 \\
5 \cdot 0 \\
8 \cdot 8\end{array}$ & $\begin{array}{r}88 \\
89 \\
106 \\
92 \\
109\end{array}$ \\
\hline Median & $8 \cdot 41$ & 215 & 66 & 59 & $6 \cdot 3$ & $5 \cdot 0$ & 92 \\
\hline
\end{tabular}

* Average values over the period 1980-9; + average values over the period 1981-9; faverage values for the years 1980, 1985, and 1989; $\oint$ average values for the years 1985 and $1989 ; n=$ number of measurements per worker (range) 


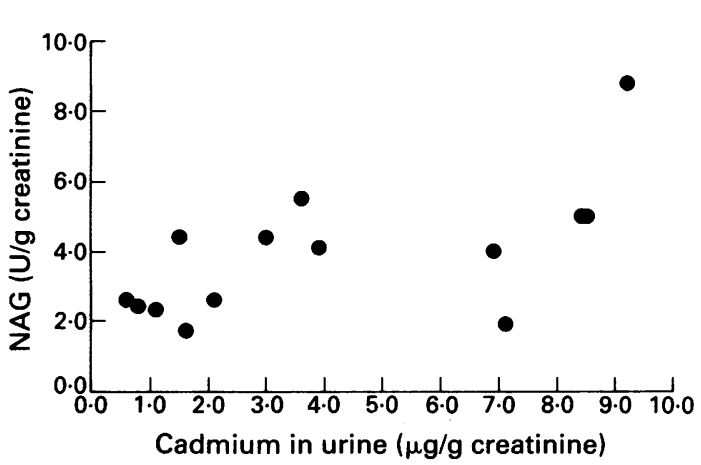

Figure 3 Urinary NAG activity in relation to urinary cadmium concentration. Average values over the period 1980-9 were used from each worker.

The average values over the period 1980-9 for urinary NAG activity and $\beta_{2}-\mathrm{M}$ and total protein concentrations were significantly correlated with urinary $\mathrm{Cd}$ concentrations ( $p<0.05$; figs $3,4,5)$. The strongest correlation was found between urinary NAG activity and Cd concentrations (coefficient of correlation $0.57 ; p=0.02$ ). For the survey of $1989(n=27)$, the significant correlations between urinary $\mathrm{Cd}$ concentration and NAG activity $(p<0.01)$ and urinary $C d$ concentration and total protein concentration $(p=0.05)$ were confirmed, but no significant relation was found between urinary $\mathrm{Cd}$ and $\beta_{2}-\mathrm{M}$ concentrations.

\section{Discussion}

The study reported here is a prospective nine year follow up study of a group of 15 workers of a Cd plant who were first assessed in 1980. Two workers left the company during the follow up, so 13 workers attended the final assessment in 1989. The aim

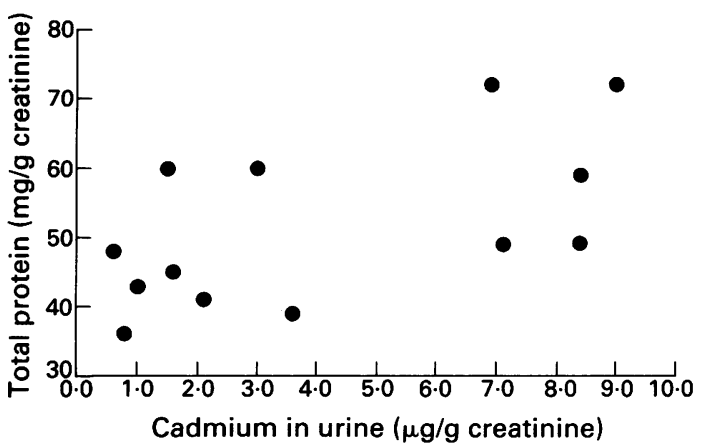

Figure 4 Urinary total protein in reation to urinary cadmium concentratrion. Average values over the period 1980-9 were used from each worker. The data point of the worker with clinical proteinuria is excluded.

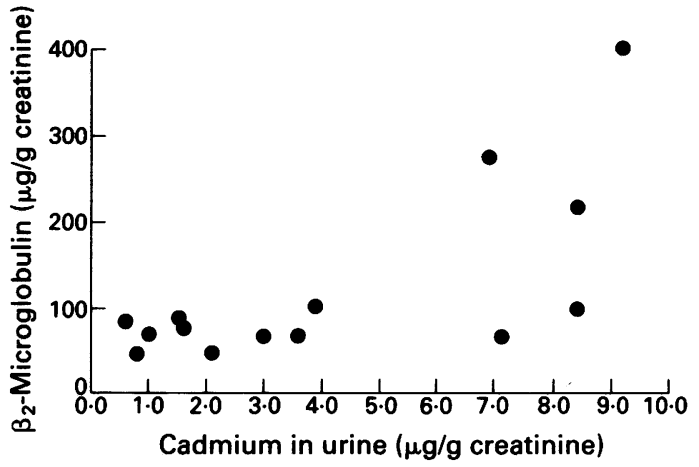

Figure 5 Urinary $\beta_{2}$-microglobulin concentration in relation to urinary cadmium concentration. Average values over the period 1980-9 were used from each worker.

was to investigate whether any renal changes related to exposure to $\mathrm{Cd}$ could be detected since 1980 by a battery of renal tests, and to assess doseresponse relations. This is important in view of the findings of Piscator and Roels et al that proteinuria induced by $\mathrm{Cd}$ is irreversible and progressive. ${ }^{2810}$

With regard to exposure, there was a significant decrease in $\mathrm{Cd}$ concentrations in blood during the period 1980 to 1985 , probably reflecting the declining exposures to $\mathrm{Cd}$. No further significant decrease in Cd concentrations in blood was found in samples collected in 1989, neither in the four workers who were transferred to another part of the zinc refinery without exposure to $\mathrm{Cd}$ nor in the workers who remained employed in the $\mathrm{Cd}$ section. This indicates that Cd concentrations in blood in 1989 probably reflect the body burden of past exposures to $\mathrm{Cd}$ and may decrease in accordance with the half life of $\mathrm{Cd}$ in blood, which is in the range of 10 to 20 years. ${ }^{26}$ On the other hand $\mathrm{Cd}$ concentrations in blood may also reflect the settling of a new equilibrium related to low $\mathrm{Cd}$ intake. Urinary Cd concentrations did not change significantly during the follow up period. This may indicate that the Cd body burden measured in 1989 did result from exposures to $\mathrm{Cd}$ before 1981 and that later exposures did not contribute much to the present body burden. The unchanged concentrations also confirm the long biological half life of $\mathrm{Cd}$ in humans. The average individual urinary $\mathrm{Cd}$ values over the whole survey period varied from 6.9 to $9.2 \mu \mathrm{g} / \mathrm{g}$ creatinine (median $8.4 \mu \mathrm{g} / \mathrm{g}$ ) for workers in group $\mathrm{A}$ and from 0.64 to $7 \cdot 1 \mu \mathrm{g} / \mathrm{g}$ creatinine (median $1.9 \mu \mathrm{g} / \mathrm{g}$ ) for workers in group B.

For the renal parameters, urinary $\beta_{2}-\mathrm{M}$ concentrations close to or marginally above the upper normal limit of $200 \mu \mathrm{g} / \mathrm{g}$ creatinine were found during the follow up period in three of four workers of the high exposure group A. The highest concentration in an individual worker was $506 \mu \mathrm{g} / \mathrm{g}$ creatinine and 
was measured during the last survey. In 1980, this worker's $\beta_{2}-M$ concentration was $400 \mu \mathrm{g} / \mathrm{g}$ creatinine. Statistical analysis of his $\beta_{2}-M$ values between 1980 and 1989 showed that there was no significant time trend. This was also the case for the other three workers in group $\mathrm{A}$. The conclusion is that no significant changes in urinary $\beta_{2}-\mathrm{M}$ concentrations occurred after the initial measurements in 1980. Retinol binding protein, the other low molecular weight protein used to detect impairment of proximal tubular function, was only measured in 1989. A significant correlation was found in the 1989 survey between the urinary $\beta_{2}-M$ and retinol binding protein concentrations (coefficients of correlation $0.676 ; n=13$ ). The retinol binding protein values of all workers in groups A and B were within normal limits. This may mean that urinary $\beta_{2}-\mathrm{M}$ is a more sensitive indicator to detect $\mathrm{Cd}$ induced impairment of proximal tubular function than urinary retinol binding protein. The results for urinary $\beta_{2^{-}}$ $M$ and retinol binding protein excretions suggest that tubular dysfunction in workers of group A, if present, was mild and not progressive. This was corroborated by the fact that urinary NAG activity was within normal limits for all workers at all times.

The values for urinary total protein and albumin were within normal limits during the follow up period, except for one case of clinical proteinuria in a worker in group B, as discussed previously. No time trends were found, which shows that no increase in glomerular permeability occurred in any worker.

Serum creatinine and serum $\beta_{2}-\mathrm{M}$ concentrations were within normal limits during the first survey (1980), indicative of a normal glomerular filtration rate. Serum creatinine concentration decreased significantly during the follow up period, which was unexpected because serum creatinine concentrations increase with age. Nevertheless, the absence of any abnormal results and of a time trend to higher values shows that there was no $\mathrm{Cd}$ induced reduction of glomerular filtration rate over time in any of the workers.

In summary, in the present study no signs of $\mathrm{Cd}$ induced low or high molecular weight proteinuria or enzymuria were found in subgroup $\mathrm{B}$, comprising nine workers (initially 11) who had been employed on average for 12 years in the $\mathrm{Cd}$ plant and who had urinary $\mathrm{Cd}$ concentrations ranging from $0.64-7.1 \mu \mathrm{g} / \mathrm{g}$ creatinine (median $1.9 \mu \mathrm{g} / \mathrm{g}$ creatinine). In subgroup $A$, comprising four workers who had worked in the $\mathrm{Cd}$ plant on average for 22.3 years and who had urinary $\mathrm{Cd}$ concentrations ranging from $6.9-9.2 \mu \mathrm{g} / \mathrm{g}$ creatinine (median 8.4 $\mu \mathrm{g} / \mathrm{g}$ ), there were signs of a slight, non-progressive, $\beta_{2}$-microglobinuria in three or four workers, but high molecular weight proteinuria, enzymuria, or a change in glomerular filtration rate could not be detected.

The findings in our study contrast with the results of follow up studies by other authors. In a retrospective study, Roels et al showed a trend towards increasing serum creatinine and urinary $\beta_{2}$ $M$ values in 19 workers who were removed from exposure to $\mathrm{Cd}$. The mean urinary $\mathrm{Cd}$ concentration in the last year of examination was $16.4 \mu \mathrm{g} / \mathrm{g}$ creatinine and urinary $\beta_{2}-\mathrm{M}$ concentrations ranged from 340 to $84650 \mu \mathrm{g} / \mathrm{g}$ creatinine. ${ }^{8}$ In another study, the same group carried out a five year follow up study on 23 workers with previous high exposure to $\mathrm{Cd}$. It was confirmed that proteinuria induced by $\mathrm{Cd}$ is not reversible. The most important finding was a significant increase of serum creatinine and serum $\beta_{2}-\mathrm{M}$ concentrations with time, indicating a progressive reduction of glomerular filtration rate. The average urinary $\mathrm{Cd}$ concentration at the end of the study was $18 \mu \mathrm{g} / 1$. Urinary $\beta_{2}-\mathrm{M}$ concentrations ranged from 66 to $123000 \mu \mathrm{g} / \mathrm{l}$ and urinary retinol binding protein from 59 to 100000 $\mu \mathrm{g} / \mathrm{l}^{10}$ Elinder et al reported urinary $\beta_{2}-\mathrm{M}$ concentrations in the range of $70-20100 \mu \mathrm{g} / 1$ in 19 workers who had had no occupational exposure to $\mathrm{Cd}$ for five years and who had urinary Cd concentrations ranging from $2 \cdot 2$ to $44 \mu \mathrm{g} / \mathrm{g}$ creatinine (median $13.2 \mu \mathrm{g} / \mathrm{g}$ ). ${ }^{9}$ There was a trend towards higher values of urinary $\beta_{2}-\mathrm{M}$ with time. These studies show that $\mathrm{Cd}$ induced progressive low molecular weight proteinuria and progressive reduction of glomerular filtration rate occurred. Urinary Cd concentrations were much higher, however, than in our study reported here.

Studies carried out so far indicate that $\mathrm{Cd}$ induced proteinuria mainly occurs at urinary $\mathrm{Cd}$ concentrations above $10 \quad \mu \mathrm{g} / \mathrm{g}$ creatinine. ${ }^{13469}$ Occasionally, however, either a slight low or high molecular weight proteinuria was also found at lower concentrations. ${ }^{256}$ In the study reported here, significant correlations between values for urinary Cd and urinary NAG, $\beta_{2}-M$, and total protein (average values 1980-9) were found, indicating possible $\mathrm{Cd}$ induced effects at urinary $\mathrm{Cd}$ concentrations below $10 \mu \mathrm{g} / \mathrm{g}$ creatinine. The strongest correlation was found with urinary NAG activity and a rise in NAG values could already be seen in the subgroup with a median urinary $\mathrm{Cd}$ concentration of $3.3 \mu \mathrm{g} / \mathrm{g}$ creatinine (table 6 ). This finding is in accordance with the previous work of Kawada et al and Chia et al who reported significant correlations below a urinary Cd concentration of $10 \mu \mathrm{g} / \mathrm{g}$ creatinine ${ }^{1415}$ Urinary NAG values in our study were all within normal limits of the reference group, however, and do not indicate renal tubular damage. The significant correlation more likely reflects a response of urinary NAG on the renal store of $\mathrm{Cd} .{ }^{27}$ 
The significant correlation between urinary $\mathrm{Cd}$ and total protein also occurred within the normal limits of total protein excretion. A small rise in total protein excretion was only seen in the subgroup with a median urinary Cd concentration of $8.4 \mu \mathrm{g} / \mathrm{g}$ creatinine (table 6). An increase of urinary $\beta_{2}-\mathbf{M}$ excretion was also seen in this subgroup. The average $\beta_{2}-M$ value (1980-9) in three of five workers in this subgroup was slightly above the upper normal limit of urinary $\beta_{2}-\mathrm{M}$ excretion. The dose-response seemed to be of the hockey stick type, with a rise in urinary $\beta_{2}-\mathrm{M}$ excretions occurring between 4 and 7 $\mu \mathrm{g} / \mathrm{g}$ creatinine. This is in accordance with earlier work. $^{2}$

Thus increased amounts of urinary NAG, total protein and $\beta_{2}-M$ were seen in relation to increased urinary $\mathrm{Cd}$ concentrations. Only for urinary $\beta_{2}-\mathrm{M}$ were changes seen close to or marginally above the upper normal limit. The dose-response relations between urinary $\mathrm{Cd}$ and these renal variables were similar during the health assessments between 1980 and 1989, indicating no progression to higher values in any of the renal tests.

From the data in this study a biological limit value of $\mathrm{Cd}$ in urine of $10 \mu \mathrm{g} / \mathrm{g}$ creatinine for workers exposed to $\mathrm{Cd}$, set by the American Conference of Governmental Industrial Hygienists ${ }^{11}$ and proposed by Bernard and Lauwerys, ${ }^{12}$ therefore seems justified although the safety margin seems to be small. The World Health Organisation limit recommended and ACGIH (1992-3) proposed limit of $5 \mu \mathrm{g} / \mathrm{g}$ creatinine for workers exposed to $\mathrm{Cd}$ exposed workers ${ }^{1128}$ would provide a much larger safety margin, and could be regarded as an action point for increased health surveillance.

We thank $\mathrm{H}$ van der Waal and $\mathrm{F}$ Wijnbeek (Biomedical Laboratory, Shell Nederland Raffinaderij, B V Rotterdam) for technical assistance, A Bernard (Industrial Toxicology Unit, University of Louvain, Brussels) for carrying out urinary albumin and retinol binding protein tests in the 1989 survey, J H M Souverijn (Clinical Chemical Laboratory, University Hospital, Leiden) for carrying out urinary albumin measurements in the 1985 survey and R R Lauwerys (Industrial Toxicology Unit, University of Louvain, Brussels) for reviewing the manuscript.

\section{Requests for reprints to: Dr N J van Sittert.}

1 Bernard A, Buchet JP, Roels H, Masson P, Lauwerys R. Renal excretion of proteins and enzymes in workers exposed to cadmium. Eur J Clin Invest 1979;9:11-22.

2 Piscator M. Long-term observations on tubular and glomerular function in cadmium exposed persons. Environ Health Perspect 1984;54:175-9.

3 Elinder CG, Edling C, Lindberg E, Kagedal B, Vesterberg O. Assessment of renal function in workers previously exposed to cadmium. Brf Ind Med 1985;42:754-60.

4 Smith NJ, Topping MD, Stewart JD, Fletcher JG.
Occupational cadmium exposure in jig solders. $\mathrm{Br} \mathcal{F}$ Ind $\mathrm{Med}$ 1986;43:663-6.

5 Verschoor M, Herber R, Van Hemmen J, Wibowo A, Zielhuis $R$. Renal function of workers with low-level cadmium exposure. Scand f Work Environ Health 1987;13:232-8.

6 Bernard AM, Roels H, Cardenas A, Lauwerys R. Assessment of urinary protein and transferrin as early markers of cadmium nephrotoxicity. Br f Ind Med 1990;47:559-65.

7 Mueller PW, Smith SJ, Steinberg KK, Thun MJ. Chronic renal tubular effects in relation to urine cadmium levels. Nephron 1989;52:45-54.

8 Roels H, Djubgang J, Buchet JP, Bernard A, Lauwerys R. Evaluation of cadmium-induced renal dysfunction in workers removed from exposure. Scand $\mathcal{f}$ Work Environ Health 1982;8:191-200.

9 Elinder CG, Edling C, Lindberg E, Kagedal B, Versterberg O. $\beta_{2}$-microglobulinuria among workers previously exposed to cadmium: follow-up and dose-response analyses. $\mathrm{Am} \mathcal{F}$ Ind Med 1985;8:553-64.

10 Roels HA, Lauwerys RR, Buchet JP, Bernard AM, Vos A Oversteyns $M$. Health significance of cadmium induced renal dysfunction: a five year follow up. $\mathrm{Br}$ F Ind Med 1989; 46:755-64.

11 American Conference of Governmental Industrial Hygienists. Threshold limit values for chemical substances and physical agents and biological exposure indices. Cincinnati: ACGIH, 1992-1993.

12 Buchet JP, Roels H, Bernard A, Lauwerys R. Assessment of renal function of workers exposed to inorganic lead, cadmium or mercury vapor. $\mathcal{F}$ Occup Med 1980;22:741-50.

13 Van Sittert NJ, Kummer R. Renal effects in workers exposed to cadmium in a cadmium producing plant. In: Brown SS, Savory J, eds. Chemical toxicology and clinical chemistry of metals. New York: Academic Press 1983;139-43.

14 Kawada T, Koyama H, Suzuki S. Cadmium, NAG activity, and $\beta_{2}$-microglobulin in the urine of cadmium pigment workers. Br F Ind Med 1989;46:52-5.

15 Chia KS, Ong CN, Ong HY, Endo G. Renal tubular function of workers exposed to low levels of cadmium. $\mathrm{Br} \mathcal{F}$ Ind Med 1989;46:165-70.

16 Schardijn G, Statius van Es LW, Swaak AJG, Kager JCGM, Persijn JP. Urinary $\beta_{2}$-microglobulin in upper and lower urinary tract infections. Lancet 1979;i:805-7.

17 Alt F. Vergleichende Bestimmung von Cadmium in Blut mit vier verschiedenen Verfahren. Fersenius $Z$ Anal Chem 1981; 308:137-42.

18 Bullock DG, Smith NJ, Whitehead TP. External quality assessment of assays of lead in blood. Clin Chem 1986;32: 1884-9.

19 Horak E, Hopfer SM, Sunderman FW. Spectrophotometric assay for urinary $\mathrm{N}$-acetyl- $\beta$-D-glucos- aminidase activity. Clin Chem 1981;27:1180-5.

20 Piscator M. Proteinuria in chronic cadmium poisoning: I. An electrophoretic and chemical study of urinary and serum proteins from workers with chronic cadmium poisoning. Arch Environ Health 1962;4:607-21.

21 Laurell CB. Electroimmuno Assay. Scand f Clin Lab Inv est suppl 1972;124:21-37.

22 Bernard A, Lauwerys RR. Continuous flow system for the automation of latex immunoassay. Clin Chem 1983;29: 1007-11.

23 Bernard A. The detection of early nephrotoxic effects. Development and validation of screening tests through clini$\mathrm{cal}$, epidemiological and experimental studies. $\mathrm{PhD}$ thesis. University Catholique de Louvain 1988;59.

24 Lehmann EL. Non parametrics, statistical methods based on ranks. San Francisco: Holden-Day, 1975.

25 Chavers BM, Bilous RW, Ellis EN, Steffes MW, Mauer M Glomerular lesions and urinary albumin excretion in type I diabetes without overt proteinuria. New Engl $\mathcal{F}$ Med 1989; 320:966-70.

26 Järup MB, Rogenfelt A, Elinder CG, Nogawak, Kjellström T. Biological half-time of cadmium in the blood of workers after cessation of exposure. Scand $\mathcal{f}$ Work Environ Health 1983;9:327-31.

27 Bernard A, Lauwerys R. Cadmium, NAG activity, and $\beta_{2}$ microglobulin in the urine of cadmium pigment workers. $\mathrm{Br}$ F Ind Med 1989;46:679-80 (letter).

28 World Health Organisation Working Group. Recommended health-based limits in occupational exposure to heavy metals. Geneva: World Health Organisation, 1980;21-35. (Technical report series 647 .)

Accepted 5 October 1992 